\title{
THE FIRST EPIDEMIC OF ASIATIC CHOLERA IN LOWER CANADA, 1832
}

\author{
by \\ GEOFFREY BILSON*
}

\section{LOWER CANADA IN 1832}

IN 1832 Quebec and Montreal were the major cities of Lower Canada with populations of twenty thousand and thirty thousand respectively. The rest of the population lived in smaller towns and villages scattered along the shores of the St. Lawrence. When the ice melted in spring, much of the travel in the province was done by boat along the river systems, and the St. Lawrence was dotted with hundreds of craft of all sizes in a traffic that was difficult to regulate. Conditions in the towns and cities of the province were the usual ones of the early nineteenth century. In Quebec, most of the population lived closely packed together below the cliff that dominates the city. Montreal was less densely settled but the bulk of the population lived crowded together in the cove. ${ }^{1}$ The houses were small, dirty, and often jammed with permanent and transient residents. "It was not unusual for six or seven families to occupy a tenement formerly inhabited by one" according to one commentator who reported that in Quebec in 1831 "in a house containing two rooms... fifty persons were found ..."2. Water for the residents came from wells, from water-carriers, or directly from the river itself, and the water of the St. Lawrence was well known for its evil effects. The houses and the streets in cities and towns were dirty and piled with garbage. Slaughterhouses operated within city limits and the refuse was frequently dumped in the streets. There were few provisions for cleaning houses, yards or streets and the atmosphere was ripe with the odour of decay. These common conditions of urban life endured partly because the government of the towns was in the hands of the local magistrates rather than of muncipal governments. Lower Canada was just on the verge of incorporating the cities and giving them self-government. There was little co-ordination between local government bodies and in Quebec the magistrates were reduced to prosecuting the Inspector of Roads for failing to clean the streets of the city. ${ }^{8}$

The public health problems of Lower Canada were intensified by the waves of emigration that reached North America in the 1830s. In 1831, fifty thousand emigrants

\footnotetext{
-Geoffrey Bilson, M.A., Ph.D., Department of History, University of Saskatchewan, Saskatoon, Canada, S7N OWO.

${ }^{1}$ Lord Aylmer-Lord Goderich, 15 June 1832, Great Britain Colonial Office. Papers 42 (hereinafter C.0.42) 241 .

'Samuel Jackson, Charles D. Meigs and Richard Harlan, Report of the Commission appointed by the sanitary boards of the City Councils to visit Canada . ... Philadelphia, 1832, p. 6.

- 24 May 1832, Quebec City Hall Archives, Minute Book, Board of Health (hereinafter Minutes), vol. 1.
} 
Geoffrey Bilson

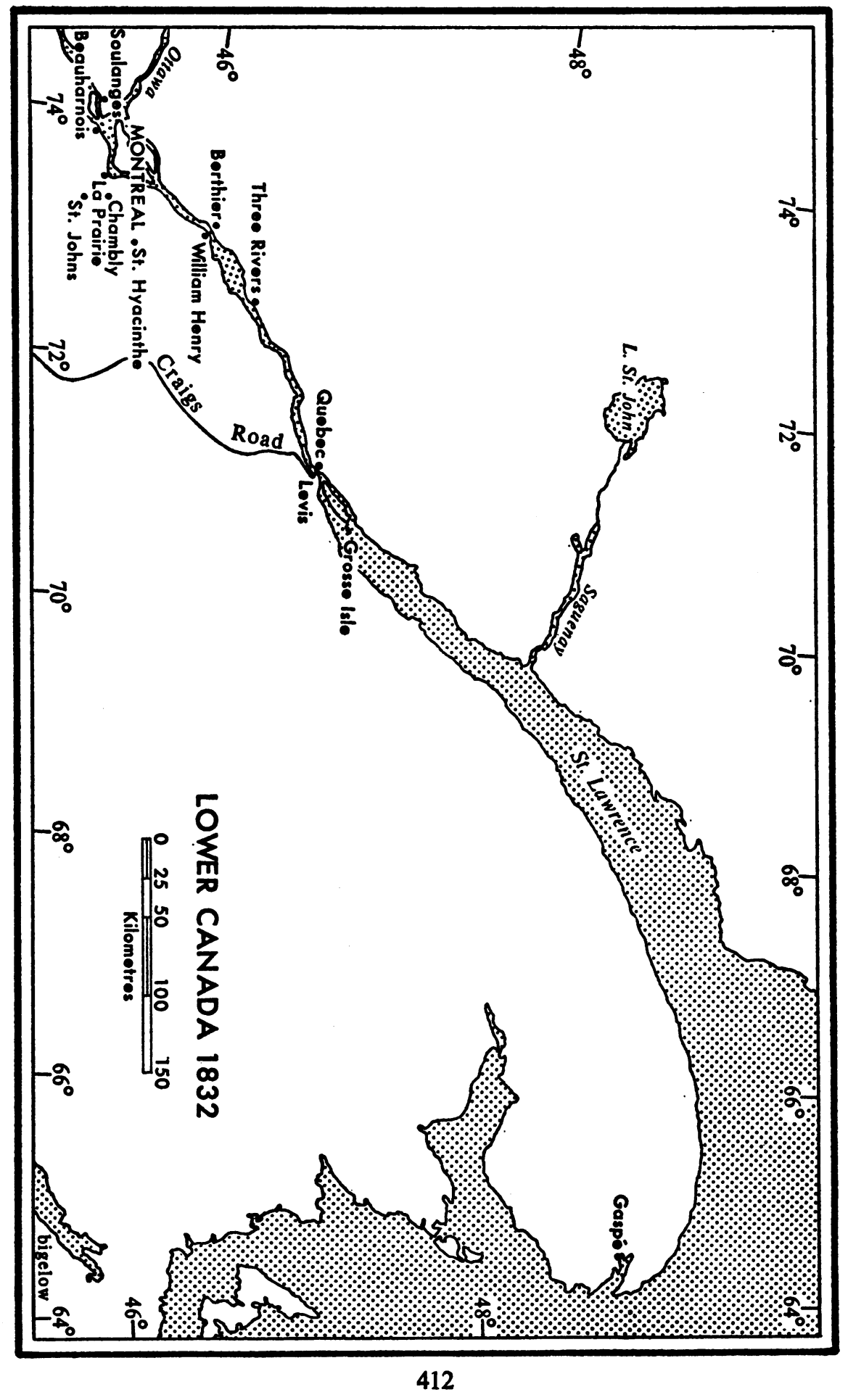




\section{First epidemic of Asiatic Cholera in Lower Canada, 1832}

had travelled along the St. Lawrence, and seventy or eighty thousand were said to be coming in 1832.4 In a year, more passengers landed in Lower Canada than in London and they strained the resources of the communities almost to the breaking point. In June of 1832, 10,599 emigrants landed in Quebec and the rate of arrivals varied between 600 and 10,000 a week through that summer. ${ }^{5}$ The emigrants jammed the houses, filled the sheds built for them, and spilled out over the beaches, the streets, and into the fields where they camped and, in some cases, died. Emigration was a contentious issue in the politics of Lower Canada as it raised economic and racial fears. The Quebec Emigrant Society, a private charitable group, claimed that the province could not support the level of emigration that was occurring, and that emigrants would find themselves unwelcome, unemployed, and destitute in a "Country, where their language is not understood, and exposed to the severities of a Canadian climate."' The Chief Emigrant Agent, Mr. A. C. Buchanan, denied the charges, claiming that they were politically inspired by French Canadians, who wanted to end British immigration, and by others who were opposed to Irish immigration. Buchanan believed that the prospects for emigrants were good provided that they were left to fend for themselves and not lulled into laziness by misdirected charitable efforts like those of the Emigrant Society. ${ }^{7} \mathrm{He}$ was right in emphasizing the ability of most emigrants to look after themselves, but each year brought its wave of exhausted, sick, and destitute migrants who could not do so. One newspaper remarked that "the effect of the transient emigration on the permanent inhabitants of Lower Canada . . . has been similar to the passage of an immense army, much exposed and ill-supplied, and leaving the inhabitants to take care of and provide for the sick, wounded and disabled, and bury their dead."8 The problems were real enough, and the British government suggested that an act be passed in Canada levying a tax of five shillings a head on emigrants to provide a fund for the support of sick emigrants and to meet the costs of forwarding the indigent to Upper Canada. The tax was imposed over the objections of those who saw it as a device to hinder British immigration. ${ }^{2}$ In 1832, the debate on immigration was intensified by the fear that there was some connexion between the emigrant traffic and Asiatic cholera.

The Canadian society that had to meet the first cholera epidemic was deeply divided and tension ridden. Conflict between religious groups and racial groups was commonplace; tension between the executive of the governor-in-chief Lord Aylmer and the Legislative Assembly of Lower Canada marked the political scene. Political disturbances were frequent and disorders reached a peak during a by-election campaign in Montreal during May of 1832. On 21 May, British troops fired into a crowd at an election meeting in the West End of Montreal, killing three men and wounding others. The province fell into uproar with public meetings of protest forming a background to a long-drawn-out judicial investigation of the incident through the spring and

-A. C. Buchanan, Report on emigration to the Canadas in 1832, 12 December 1832, C.0. 42/241. I Ibid.

- Petition, Quebec Emigrant Society, 5 December 1831, C.0. 42/236.

? A. C. Buchanan-Lord Aylmer 23 February 1832, C.O. 42/236, and Report, op. cit., note 4 above.

- Quebec Gazette, 11 November 1831.

- R. Christie, A history of the late province of Lower Canada, parliamentary and political, Quebec, T. Cary, 1850, vol. 3, pp. 382-383. 


\section{Geoffrey Bilson}

summer. No-one made a direct link between the political disturbances and the tension people endured as they waited for the cholera, but it may have played a part in the events of May, the month in which the first immigrants of the season began to arrive. For months past, the press had been printing accounts of the progress of the disease across Western Europe, its arrival in England, and had been speculating on whether it would break out in Canada. To meet that expectation the Legislative Assembly of Lower Canada passed a new Quarantine and Public Health Act in 1832 and preparations began against the disease. Not content to rely on the laws of man, the governor accepted the suggestion of the bishop of Quebec, and proclaimed 4 May 1832 as a day of humiliation "to avert the judgement earned by our sins." 10 The sense that something dreadful was about to happen pervaded the province. There were many doctors who said that cholera could erupt in Canada even before ships arrived from Britain, 11 and when news reached Quebec and Montreal of a highly fatal disease that had broken out at Lundy's Lane in Upper Canada people assumed that it was cholera. The press appealed for calm and published official denials that the disease was cholera. ${ }^{12}$ The level of panic when cholera finally did break out is a further indication of how greatly dreaded it had been.

\section{PREPARATIONS AND QUARANTINE}

In the last months of 1831 and the first months of 1832, Lord Aylmer and the Executive Council had kept a close watch on the progress of cholera. Reports in the press and official despatches from the British government kept Aylmer informed of the precautions being taken against cholera by establishing quarantine and setting up Boards of Health. ${ }^{13}$ When Aylmer read of the outbreak of cholera in England he asked the Executive Council to recommend action. On their advice he ordered that a temporary quarantine be established at the mouth of the St. Charles river to deal with vessels coming before the end of the navigation season in 1831. ${ }^{14}$ Aylmer then turned to the local medical profession and asked the Quebec Medical Board to make recommendations on public health measures. ${ }^{15}$

The medical profession of Lower Canada was not well placed to offer clear leadership to the community in 1832. There were doctors in Lower Canada who had personal experience with the disease during service with the British army in India, but doctors in Lower Canada, like medical men elsewhere, could not agree on the nature of the disease, about whether or not it was contagious or about the treatment to be used. Public confidence in doctors, reduced by their professional disagreements, was further eroded by their pretensions to professional standing. Under the terms of an act of 1831, practitioners of medicine were attempting to make a profession of medicine by restricting entry to their ranks and by raising educational barriers to entry to the study of medicine. These efforts were dividing the doctors and in Montreal

1029 March 1832, 4 April 1832, C.O. 42/237.

11 J. D. Douglas (ed.), Journals and reminiscences of James Douglas M.D., New York [n.p.], 1910, p. 134.

12 Montreal Gazette, 23 April 1832.

18 Copies or Extracts of all information . . . communicated to Government . . . 27 June 1831. Public Archives of Canada (hereinafter PAC) RG1E3, vol. 16.

16 PAC RG4A1 S-269, pp. 150, 151.

16 PAC RG4A1 S-272, p. 5. 


\section{First epidemic of Asiatic Cholera in Lower Canada, 1832}

there was a split between a group of English doctors teaching medicine at McGill and the French doctors in the city. The French doctors believed that the McGill group was trying to impose conditions for entry into the practice of medicine which were insulting to the training and skill of the French. ${ }^{16}$ Despite their internal feuds, doctors were able to draw together if they felt that their newborn professional status was threatened by laymen, and during the epidemic there were to be some incidents between Boards of Health and local medical men. The twenty-nine doctors in Quebec and eighteen in Montreal did not serve the whole population, many of whom relied on self medication or the advice of the apothecaries. Medical men in Montreal would seize the opportunity presented by the epidemic to strike against the apothecaries when Robert Nelson, acting as a prosecuting member of the Board of Health, ordered apothecaries to stop selling medicine "for Cholera or otherwise" on the grounds that apothecaries' prescriptions had made some people, who were suffering only from fear, "really ill". ${ }^{17}$ This action was widely criticized, one editor calling it "an act of unparalleled tyranny ... at a time when physicians cannot attend the half, we might believe, nay fifth of the sick in our city," while a correspondent pointed out that many people preferred the advice of an experienced druggist to that of a young fellow just out of school. ${ }^{18}$ The medical profession was unpopular with many of the residents of Lower Canada who were disturbed by its internal divisions and offended by its claims to privilege and high status. When Lord Aylmer later praised the doctors for their efforts during the epidemic, his remarks were dismissed by a commentator as "a special piece of vice royal trumpeting, savouring of the unnecessary and absurd, that had as well have been omitted."10

When Aylmer asked the Quebec Medical Board for advice, they followed the precedents of European governments. They doubted that cholera was contagious but they advised establishing a quarantine station down river from Quebec where the sick could be housed and passengers and ships be cleaned after the ocean crossing. The Board recommended that Boards of Health be set up to enforce the rules of cleanliness laid down by the Privy Council and that all information sent from England be translated into French and sent to doctors in the country. ${ }^{20}$ On the basis of this report, the House of Assembly passed the Bill to establish Boards of Health in Quebec, Montreal, and elsewhere as needed, and to enforce an effectual system of quarantine. They supported the act with an appropriation of $£ 10,000 .{ }^{21}$

The first line of defence against cholera was to be quarantine. Grosse Isle, a small hilly island thirty miles below Quebec, was chosen as the site of the station which would be supervised by the Quebec Board of Health. From the start, the quarantine regulations laid down requirements that far exceeded the resources of the island. All ships had to stop at Grosse Isle for inspection by the Health Officers. Ships from infected ports performed a three-day quarantine. Passengers of ships which had had

\footnotetext{
10 Sylvio Leblond, 'La Médecine dans la Province de Quebec avant 1847', Les cahiers des dix, 1970, 35: 69-95.

${ }_{17}$ Quebec Mercury, 23 June 1832.

18 Canadian Courant, 20 June 1832; La Minerve, 22 June 1832, 2 July 1832.

10 Christie, op. cit., note 9 above, vol. 3, p. 435.

${ }^{20}$ PAC RG4A1 S-272, p. 5.

21 Christie, op., cit., note 9 above, vol. 3, p. 386.
} 


\section{Geoffrey Bilson}

illness on board were to clean themselves while the ship was purified. A ship which had had cholera on board performed a fifteen-day quarantine and all steerage and hold passengers were landed to clean themselves and their baggage while the ship was cleaned. If a ship arrived with cholera aboard, the victims were to be taken ashore to the hospital and the remaining passengers landed while their ship was cleaned and served a thirty-day quarantine. Convalescent passengers were to be kept apart from the healthy for twenty days after their recovery. This was a system that threw a huge strain on the resources of the island and the Board recognized that if more than one ship arrived with cholera the station would be in danger of being overwhelmed. ${ }^{22}$ Yet in July, after cholera had appeared, the Board required all passengers to land and clean themselves and their baggage before going on to Quebec and on some days as many as a thousand passengers struggled for space and washing water.

The sheer volume of river and ocean traffic threw an impossible burden on the inspecting officer, Dr. George Griffin, who in any case hated going about the anchorage in an open boat and even when Dr. Charles Fortier was appointed as his assistant it was almost impossible to give all vessels stopping at the island a thorough inspection. ${ }^{23} \mathrm{~A}$ number of vessels slipped by the island to be sent back by the authorities from the landing at Quebec where a secondary inspection was maintained at the mouth of the St. Charles River. Despite this precaution, passengers sometimes landed without inspection, as did those of the brig Fanny in July. ${ }^{24}$ In some vessels that were inspected, passengers hid sick members of their families to avoid the long delays of quarantine. Conditions on the island threw together sick and well and did little to protect the public health. The quarantine was so ineffective that the Quebec Board of Health debated closing down Grosse Isle when cholera broke out in the city. They decided to keep it in operation despite the uncertain value of quarantine because it was "adequate to the removal of a particular and known cause of evil ... it will enable us to disinfect a ship ... whereas if there be no such place as Grosse Isle or yet any substitute for it that evil is without remedy." 25

The Quebec Board of Health was in operation early in 1832 largely because it had work to do setting up Grosse Isle. Mainly composed of laymen, the Board turned its attention to preparing the city for the assault by cholera. It was required to provide hospitals and to clean the city. Hospital space was limited in Lower Canada, in Quebec the four civilian hospitals contained fewer than three hundred beds. A new Marine Hospital was under construction but would not be finished until 1834. In Quebec, patients with contagious diseases were barred from all but the Point Levi Hospital, which lay across the river from the city and was sometimes inaccessible. ${ }^{26}$

22 Reports of Quebec Board of Health 26 March 1832, 29 March 1832, 30 March 1832, PAC RG4A1 S-279, pp. 77, 78, 111, 112, 121.

23 Dr. G. Griffin to Sec. Craig 16 May 1832, PAC RG4A1 S-282, p. 3; Board of Health resolutions 19 May 1832, ibid., p. 32; Dr. G. Griffin to Sec. Craig 24 May 1832, ibid., p. 58; Capt. H. Reid to Col. Clegg 10 July 1832, PAC RG8C vol. 300 nos. 117-119; Capt. R. Reid to Sec. Craig 17 July 1832, PAC RG4A1 S-286, pp. 20-21.

24 Board of Health to Sec. Craig 14 July 1832, PAC RG4A1 S-285, pp. 116-117.

25 Report of Committee of Board of Health 26 June 1832 PAC RG4A1 S-284, p. 137.

${ }^{26}$ Sylvio Leblond, 'Quebec en 1832', Laval médical, February 1967, 38: 184-185. 
In Montreal, the Montreal General Hospital, which was closed to patients with infectious disease in normal times, barred cholera victims in 1832. ${ }^{27}$ Now, the Boards had to provide for patients barred from existing hospitals yet likely to be present in numbers that would overwhelm all existing hospital space. In mid-March the Quebec Board of Health recommended that Point Levi Hospital be closed down and the Emigrant Hospital, which was in the city, be taken over for cholera cases and enlarged with sheds in the yard and by hiring a house across the street which would hold sixty patients. They also recommended that the government be asked to provide tents for a hospital for the sick who would land at King's Wharf. ${ }^{28}$ The news that the Emigrant Hospital was to be used as a cholera hospital brought a petition of protest supported by nineteen double columns of signatures and Xs from the residents of St. John suburbs. These poor people protested against the presence of the Emigrant Hospital in their midst, as they had in the past, but now they said the situation was one hundredfold more serious. The board replied that a well-run hospital was less dangerous to public health than were the crowded houses of the very poor and tried to calm the local residents' fears. The fact that it assumed the people were fearful of smallpox now, as they had been in the past, was disingenuous to say the least. ${ }^{29}$ In Montreal, no efforts were made by any authority to prepare hospitals for cholera patients before the epidemic began. ${ }^{30}$

Following the example of Britain, the authorities in Lower Canada put great emphasis on sanitary measures as a means of preventing the outbreak or spread of cholera. In March, the Quebec Board of Health began the work of cleaning up the city and again it laid down elaborate regulations, as it had for Grosse Isle, which, while ideal, were beyond the resources at its command. The city was divided into fourteen wards and a warden appointed for each, with two appointed for the Lower Town. It took a month to fill the positions. ${ }^{31}$ The fifteen Health Wardens were issued with ribbons and badges and given a sign to nail up outside their houses. They were required to list every house and apartment in their ward and to keep a list of residents. They were given the power to inspect private property and were required to visit every house in their ward three times a week and make daily reports to the Board. The wardens distributed medicine to the sick poor, cleared condemned buildings of squatters, rounded up pigs, and brought delinquents to the notice of the Board. The work was demanding, sometimes dangerous, and it paid five shillings a day. The fifteen men were soon overwhelmed by the work. ${ }^{32}$

The health regulations that the wardens were required to enforce attempted to clear the city of accumulated filth within two weeks in the spring. Houses were ordered to be cleaned and whitewashed, rubbish carted away, and slaughterhouses moved to the St. Charles river where the refuse could be dumped below low water mark. The timetable was impossible to meet and the Board extended the clean-up

27 Montreal General Hospital Minutes, 15 June 1832, McGill University Archives 1501/3A.

2820 March 1832, 17 April 1832, 25 May 1832, Minutes vol. 1.

208 May 1832, ibid; Board of Health-Sec. Craig 18 May 1832, PAC RG4A1 S-282, pp. 11-14.

${ }^{20}$ Jackson et al., op. cit., note 2 above, p. 11.

3116 March 1832, 16 April 1832, 28 April 1832, Minutes vol. 1.

825 April 1832, ibid.; 30 July 1832, Minutes vol. 2. 


\section{Geoffrey Bilson}

into the second week of May. ${ }^{33}$ Public inertia and open resistance to the sanitary regulations continued before and during the epidemic, sustained in part by the fact that it was difficult to prove any connexion between the standard filth of the communities and the new disease. In Montreal no effort was made to prepare the city although it was known that there was more sickness than usual with twice the number of fever cases in hospital in the winter of 1831-1832 than the winter before. ${ }^{34}$

The months of tension and preparation culminated in the opening of navigation on the St. Lawrence. Four hundred ships carrying twenty-five thousand emigrants had reached Quebec by the end of the first week of June. They were watched anxiously by the citizens, who were aware that Dr. F. X. Tessier, the Health Officer, was unable to inspect all the craft which reached the city. Late in May, a child who had been smuggled past Grosse Isle died in Quebec. ${ }^{35}$ Rumours began to circulate in the city early in June that Asiatic cholera victims were at the Emigrant Hospital. The rumours were correct, although the doctors were slow to grasp the fact.

\section{THE EPIDEMIC IN QUEBEC AND MONTREAL}

On 6 June, Dr. Joseph Morrin, the Health Commissioner, and T. A. Young, Secretary of the Board of Health, left Quebec for Grosse Isle to investigate reports of cholera at the station. The next day, the Board of Health read letters from the doctors at the island that passengers had been landed from the brig Carricks "under undoubted suspicion of the cholera morbus". On 8 June, Dr. Morrin reported that the Carricks' passengers were victims of an epidemic "in many particulars resembling Cholera" but that the "fever [was] in no particular different from many now under treatment in the Quebec Emigrant Hospital." Secretary Young issued a denial that there was cholera in the city. ${ }^{36}$ The doctors were confused, no ship with a known cholera case had reached Quebec, the first case of the illness which resembled cholera was in a resident of the city, not an immigrant. Not until 9 June, according to Dr. Joseph M. Skey, the chief military medical officer in Lower Canada, did "the truth flash on our minds" when on a visit to the hospital he, Dr. Morrin and the other physicians found "several of the cases . . . so far advanced in their progress that it was impossible not to decide upon the true nature of the disease on the very instant." No treatment helped these first victims and in less than a week one hundred and sixtyone people had died in Quebec.37

The same editions of the newspaper which carried Secretary Young's denial that there was cholera in the city carried the news that it had arrived amongst passengers of the Voyageur. ${ }^{38}$ That vessel had proceeded to Montreal where, on 9 June, most of the city's newspapers carried the report that Charles Vasseur had died, the first victim of cholera. Rumour spread rapidly, fed by contradictory reports from Quebec and silence from the magistrates. By 12 June, the Vindicator could state flatly that there was no doubt that cholera existed and demanded to know what the magistrates

235 May 1832, Minutes vol. 1.

i PAC RG4A1 S-279, pp. 130-131.

25 6 June 1832 PAC RG4A1 S-283, p. 49; 10 May 1832, 23 May 1832, Minutes vol. 1.

36 6-8 June 1832, Minutes vol. 1.

${ }^{37}$ Dr. Skey-Lord Aylmer 15 June 1832, C.O. 42/237.

${ }^{88}$ Mercury, 9 June 1832. 


\section{First epidemic of Asiatic Cholera in Lower Canada, 1832}

intended to do. On 8 June, the Montreal Board of Health held its first meeting and it spent the first days of the epidemic organizing itself, leaving "everything with regard to the sanitary police ... in confusion and neglect." ${ }^{39}$ The Montreal Board never recovered from this early failure and it lost further prestige by issuing a denial that cholera was in the city. The citizens of the town, seeing an unusual number of burials performed in the afternoon without the benefit of church services, doubted the denial. Tension mounted in Montreal until, on 12 June, the Board confirmed that ninety-four cases had occurred in the city. When it failed to make an announcement on 13 June, people assumed that the Board had news too dreadful to publish. The Courant reported that "a panic of an almost indescribable nature seems to have taken hold of the whole body of citizens and to have deprived them of presence of mind to an extent exceeding anything of a similar nature which had ever been witnessed in Montreal."40

The explosive nature of the epidemic in both Quebec and Montreal stunned the people. In Quebec, the first cases were among the boarders at Roache's boarding house on Champlain Street, a house so filthy that it was described as a public nuisance. Three other cases occurred in the house within a day. Cases soon appeared all over town at St. Angel, Baude St., Pres de Ville, L'ance des Mers, Cul de Sac, St. George St., the St. John suburbs, and nearby at Point Levi. ${ }^{41}$ The death toll mounted rapidly into the seventies, nineties, and by 15 June to well over one hundred a day. It stayed at that level for a week before beginning to decline. ${ }^{42}$ In Montreal, the first cases were near the old market house but the next were half a mile away in the St. Lawrence suburbs. Great numbers of cases then occurred in unconnected parts of the suburbs, with few cases, at first, in the town or the streets near the river or among the emigrant crowds. ${ }^{48}$ In Montreal, the deaths soared to over one hundred on 17 June, one hundred and forty-nine on 19 June, and, after dropping below one hundred on 20 June, they continued at a rate ranging from ten to forty a day until late in the epidemic. As Lord Aylmer wrote, the city had been hit "with a degree of violence far surpassing anything that has occurred in Europe, and officers now serving here assert that even in India ... the disease was never so rapidly fatal or so universal in its seizures as during the first few days of its prevelance in this place."44

The disease had struck with violence, the doctors had no success treating the victims, and the death toll threatened to depopulate the province. People tried to understand the disease, which seemed to fit no known pattern of contagion. The first victims all seemed to have lived in filth and squalor, which suggested a link between dirt and disease. The Board of Health suggested that Montreal might be peculiarly liable to the disease because of the abundance of low and marshy land,

"Jackson et al., op. cit., note 2 above, p. 11.

to Canadian Courant, 16 June 1832.

11 9-11 June 1832, Minutes vol. 2.

42 The Board of Health reports give figures for deaths in hospitals but there were many deaths outside the hospitals, and J. M. LeMoine, Quebec past and present: a history of Quebec 1608-1876, Quebec, A. Coté 1876, pp. 272-273, gives the daily rates quoted here. Lord Aylmer calculated that by the end of June, 1500 people had died in Quebec, Lord Aylmer-Lord Goderich 30 June 1832, C.0. 42/237.

" Jackson et al., op. cit., note 2 above, p. 2.

" Lord Aylmer-Lord Goderich 26 June 1832, C.0. 42/237. 


\section{Geoffrey Bilson}

with its stagnant water "filled with all the elements of miasma (pestilential effluvia)" and the large number of vacant lots covered with rotting "animal and vegetable" matter. ${ }^{45}$ On the other hand, villages which were much neater and cleaner than Montreal, soon succumbed to the disease. ${ }^{46}$ Perhaps the explanation for the spread of the disease lay not so much with the physical conditions of the province as with the character of the people, and there were those who felt that the victims of the disease were found among those who exposed themselves to it by immoderate behaviour. Dr. Skey felt that there were many in Quebec "who from a combination of moral and physical causes, were just of the description likely to suffer the extreme violence of the disease." 47 The Boards of Health urged moderation in eating and drinking as the key to survival..$^{48}$

The possible link between poor physical conditions and moral failings in explaining the pattern of the disease gave the more affluent citizens of the province some comfort while cholera ravaged the poor. When it began to attack their own kind the middle classes were greatly disturbed. The deaths of Louis Lagueux, a member of the provincial parliament, and of Judge Jean Thomas Taschereau made a great impact among those who had taken comfort from the anonymity of the first victims. How could one explain the deaths amongst those "less likely to suffer than one would have imagined." 49 Perhaps it was due to the personal failings of the victims, but there was no pattern there-Judge Taschereau had been timid and anxious and had succumbed, but Lagueux had been resolute "boasting . . . that people should stand it en grenadier. At midnight he was attacked and at seven this morning he was a corpse." ${ }^{50}$ Neither timidity nor resolution had any effect on the disease.

In the circumstances, it is not surprising that the first response to the disease was flight. Rich and poor fled the cities to escape the death toll that mounted every day. In Montreal, the editor of the Gazette appealed to the people to stay calm in an edition reduced to half a sheet "from many of those in our employ being absent during this period of alarm." "51 Business slowed down as men shut their shops. Boatmen deserted the river from Quebec to Upper Canada forcing many of the steamboats that plied between Quebec and Montreal to be laid up, while the smaller sailing vessels were abandoned on the shore by their crews. It took some weeks to restore the river traffic and, when the crews could be won back, travel to Upper Canada was restricted as magistrates closed the river to vessels from Lower Canada. ${ }^{52}$ The habitants stopped coming to the towns and the supplies of fresh food declined and prices rose. This first panic eased after a couple of weeks when it became apparent that the disease was not going to depopulate the province and people came to terms with the fact that the epidemic was one more burden to carry and endure. Taverns and groceries did a good business despite all appeals for moderation and warnings of the evil effects of drink.

45 Montreal Gazette, 16 June 1832.

4617 July 1832 Lord Aylmer-Lord Goderich, C.O. 42/237.

17 Dr. J. M. Skey-Sec. Craig 15 June 1832 PAC RG4A1 S-283, p. 133.

48 E.g. Regulations of Montreal Board of Health, Montreal Gazette, 16 June 1832.

6 Dr. J. M. Skey-Sec. Craig 15 June 1832, PAC RG4A1 S-283, p. 133.

${ }^{30}$ Samuel Neilson notes PAC MG24B1 vol. 42, p. 1747.

${ }^{61}$ Montreal Gazette, 16 June 1832.

32 Buchanan, op. cit., note 4 above. 


\section{First epidemic of Asiatic Cholera in Lower Canada, 1832}

The panic of these early weeks hit hard at the emigrants. Residents avoided them and barred their houses to them, forcing them to crowd together in those houses which would accept them, or to live on the streets. Travel on the river was halted and travel on land was made difficult by the attitude of the villages through which the emigrants had to pass. ${ }^{53}$ One fact made conditions easier than they might have been. The peak of the emigrant wave was reached in the week before cholera broke out, ten thousand emigrants arrived in Lower Canada in the week ending 9 June. For the next two weeks, while the panic was at its height, the numbers dropped below two thousand five hundred and the problem of dispersing them or accommodating them was much less acute. Agent Buchanan concentrated on forwarding the travellers from Quebec as quickly as he could although that meant that numbers of emigrants piled up at Montreal before the magistrates of Upper Canada could be persuaded to reopen the river. ${ }^{54}$

The Boards of Health in both major cities had three essential tasks when the epidemic began. They had to house the emigrants, they had to increase the medical care available for the poor and they had to enforce the sanitary laws. In Quebec, the Board met the problem of housing emigrants both by maintaining the sheds which had been used in the past and by opening a tented camp on the Plains of Abraham. Using tents lent by the army, the Board opened the camp on 15 June and used it to house those named by the Quebec Emigrant Society. The camp also offered temporary accommodation to people who were turned out of their houses while they were being cleaned. Before it was closed down in October the camp sheltered hundreds, straining its facilities to breaking point but easing some of the pressure on the city. ${ }^{55}$ In Montreal, no similar provisions were made, but the situation for emigrants was in fact made more difficult because the Board seized the emigrant sheds and used them as cholera hospitals, leaving the emigrants to fend for themselves until voluntary organizations provided accommodation. ${ }^{56}$

The action of the Montreal Board was a direct consequence of their failure to provide hospital space before the epidemic began. With cholera in the town, the Board could offer the victims only the sheds, one without a floor, where the patients lay on straw "exposed indiscriminately to the open windows and doors-men, women and children; the convalescent, dying and the dead laid in an irregular line along the sides of the building." 57 The Montreal General Hospital continued to refuse to admit cholera patients, or even to erect a shed for them on its grounds, and the Board was forced to build a second cholera hospital, a rough shed on the Rue St. Denis. One paper said that the Montreal hospitals "might be more properly called dying houses than hospitals." 58 Not until late June was a doctor appointed as a non-resident, part-time, supervisor and the minimum equipment and supplies made available for the hospitals. ${ }^{59}$

s Ibid.

st Ibid.

6s 15, 16 June 1832, Minutes vol. 2; 22 August 1832; 29 September, Minutes vol. 3.

se Jackson et al., op. cit., note 2 above, p. 6.

s7 J. R. Rhinelander, J. E. DeKay, Report of the Commissioners employed to investigate the origin and nature of the epidemic cholera of Canada, New York, 1834, p. 33.

s8 Canadian Courant, 20 June 1832.

- Montreal Gazette, 28 June 1832, 30 June 1832. 


\section{Geoffrey Bilson}

In Quebec, the situation was slightly better because of the preparatory work done by the Board. When the epidemic began the Board was able to send victims to the expanded Emigrant Hospital. A petition was soon organized, supported by thirteen pages of signatures, pleading for an end to the practice. The Quebec Mercury supported the protests, saying that the people were endangered and disheartened by the sight of the sick being carried through the town to the hospital and the dead being carried from it. ${ }^{60}$ The Board rented two buildings nearer the shore, despite protests from the neighbours and from the magistrates, and later opened a hospital in tents at St. John Suburb. Supervising physicians were appointed when the hospitals were established. ${ }^{61}$ In later years, there were direct physical assaults on buildings rented as cholera hospitals, but in this first epidemic protests were limited to petitions, editorials or occasional refusals to rent buildings to the Boards.

The Quebec Board of Health estimated that two out of three cases went to the hospitals, but that may have been an exaggeration. People resisted being taken to hospital or having their relatives sent there-one man's relatives refused to let him go to hospital "being able to pay" 62 and the social stigma and implicit death sentence of being ordered to hospital stimulated resistance. Even so, the hospitals were swamped with patients in the first days of the epidemic and the results approached chaos. The Emigrant Hospital was so crowded and filthy that the doctors working there had to wear overshoes; the matron abused the staff and was said to rob the dead. Admissions were delayed as doctors sought permission from the Board. ${ }^{63} \mathrm{Dr}$. A. von Iffland, one of the supervising physicians, worked for the first two weeks without removing his boots and "when he did, the flesh adhered to the sole leather." When after the first weeks, some order was imposed the hospitals continued to have great difficulties as the nurses would leave even when by doing so they forfeited their pay. ${ }^{64}$

The Boards had to provide medical aid for those poor who did not go to hospital. In both cities, they gave medicines to the Health Wardens "to distribute to the poorer classes." 65 In both Quebec and Montreal depots marked by a yellow flag were set up with medical supplies for the poor. ${ }^{66}$ The Resident Physicians appointed by the Board were expected to provide help but they were overworked and sometimes careless, and the Quebec Board once reprimanded Dr. William Hall, a resident physician, for refusing to call at 11.00 p.m., and reminded all doctors that they were "bound to visit without delay all patients labouring under cholera when reported to them ...."ק7 Some doctors helped the poor, some were reluctantly forced into helping them, like Dr. Drolet of St. Roche, Quebec, who claimed that his own practice was being hurt because of the flood of poor patients in the early days of the epidemic. He threatened to "attend to nothing but my private practice" if the Board did not provide an

${ }^{\circ 0} 13$ June 1832 PAC RG4A1 S-283, pp. 98-109; Quebec Mercury, quoted in Montreal Gazette, 16 June 1832.

612 June 1832, Minutes vol. 1.

12 Ibid.

- Rapport du Comité Permanent de la Faculté de Médecine de la Cité de Quebec, Quebec, 1832, 19 November 1832.

"4 LeMoine, op. cit., note 42 above, pp. 271-272.

os 21 June 1832, Minutes vol. 2.

Co 20, 21 June 1832, ibid.; Montreal Gazette, 26 June 1832.

'7 20, 23 October 1832, Minutes vol. 3. 


\section{First epidemic of Asiatic Cholera in Lower Canada, 1832}

indemnity, but the Board had no money for indemnities and had to ask Drolet to "continue to give your charitable assistance to the poor." There is no record of Drolet's response. ${ }^{68}$

The bulk of the poor must have gone without help from professional physicians, who had little enough to offer them but a brutal regimen of bleeding, mercury, and opium at prices ranging up to $f 5$ a visit. ${ }^{99}$ The apothecary, self-help, and the care of friends and neighbours were the resources for most people. In Quebec, the residents of St. Roche petitioned the Board asking for a reward for Jacques Hamel, a blacksmith who abandoned his shop in order to go all over the city to help the poor and the workers. ${ }^{70}$ The clergy, too, laboured among the poor, closing down the Seminary to free the teachers for pastoral work. Most famous of all the helpers of the poor was Stephen Ayres "the cholera doctor," who appeared in Montreal late in June. Leading a couple of thin horses and dressed in an old shabby hat, a blanket coat, and sporting a long black beard and long hair, he moved about the city treating victims with a medicine of lard, charcoal, and maple syrup, and ordering massage for the cramps. He took no money and quickly won a reputation as "a Saint, sent to save them in their dreadful time ...". ${ }^{71} \mathrm{He}$ was soon being followed about town by crowds of hundreds as he went from house to house. The story spread that he had arrived with the cholera and when he left on 29 June, the cholera would go with him. Neither he, nor the disease, left Montreal that day, but he continued to work from an office in the centre of the town, open to all from 8.00 a.m. to 7.00 p.m. ${ }^{72}$

Controversy enveloped Ayres. He was denounced by medical men as a fraud and charlatan and defended by his supporters for charging no fee and for calming the fears of hundreds of Montrealers. In July, controversy deepened when Ayres accepted an invitation to visit the Caughnawaga Indian Reserve, where the Indians had been brutally used by cholera with seventy deaths between 18 June and early July. After Ayres' visit, one of his supporters published a pamphlet praising his work on the reserve and contrasting it favourably to that of Father Marcoux, the resident missionary. Ayres found himself embroiled in a controversy with the defenders of the church but he retained his popularity in the city along with the air of mystery he cultivated. ${ }^{73}$ Ironically, Ayres was himself a licensed physician from New Jersey who had travelled to Montreal on non-medical business but stayed to help the sick. After the epidemic, he petitioned the government for some compensation for himself and his assistant, claiming to have cured eight of ten cases. There were no funds from which to reward him. ${ }^{74}$ His popularity suggests something of the panic and fear in Montreal in the summer of 1832.

The bulk of the work of the Boards of Health had to do with enforcing the sanitary laws and developing public health standards. The attempts of the Boards to deal with these questions brought them into conflict with the medical profession. Private

Co 13 June 1832, Minutes vol. 1.

-Vindicator, 26 June 1832.

7030 August 1832, Minutes vol. 3.

11 Canadian Courant, 23 June 1832.

72 Advertisement, La Minerve, 28 June 1832.

73 Ibid., 30 July 1832, 6 August 1832,

" PAC RG8C vol. 301, pp. 122-125. 


\section{Geoffrey Bilson}

practitioners and the Boards' own employees were quick to resent what they regarded as lay interference in professional matters. In June, the Quebec Board criticized one of its members, the Reverend Dr. Harkness, for his treatment of one of the doctors at the Emigrant Hospital. In July, Dr. William Lyons resigned as superintendent of the hospital because he felt that the Board's plan to supervise the hospital reduced his professional standing. ${ }^{75}$ Dr. F. X. Tessier, the Health Officer at Quebec, was suspended and later dismissed for incompetence and for collecting fees for health certificates which he issued on his own initiative to ships' captains. ${ }^{76}$ In Montreal, the Board came into conflict with the Health Commissioner, Dr. Robert Nelson, who tried to maintain control over the money paid by the province to the Board. He was so insulted when the money was paid to the Chairman of the Board that he refused to sign the cheques as he was required to do. The Governor-in-Chief had to be called on to end the impasse. 77

In Quebec, the Board found itself in difficulties with the entire profession and not merely those members of it in its employ. The regulation that doctors report on the death of cholera patients produced a complete rupture between Board and doctors. The Board hoped to keep a check on the progress of the disease and to arrange to inspect the houses of victims on the basis of the doctors' reports, and it met charges of inefficiency by criticizing doctors who failed to report deaths. It then began to prosecute doctors for failing to make the reports. The prosecutions of Drs. Seguin and Rowley enraged many doctors as a slur on the profession. Half the doctors of the city met and set up a committee to police the activities of the Board and to administer a defence fund for doctors who were prosecuted. The committee later produced a report that was bitterly critical of the inefficiencies of the Board, especially in their administration of the hospitals. ${ }^{78}$

The Boards of Health found it very difficult to enforce the public health measures laid down by them under the Quarantine Act. In both the major cities and in the smaller centre of Three Rivers, the Boards asked the executive of Lower Canada to permit them to use extraordinary procedures to prosecute cases involving breaches of regulations. The Boards wanted to use private lawyers to prosecute cases and try summary judgements before Justices of the Peace. The governor-in-chief rejected that procedure and insisted that all actions had to be brought by the Attorney General or the Solicitor General. When the Boards objected that that requirement led to delays and heavy expenses, they were advised to distinguish between the more and the less urgent cases and to refer the less urgent to the Executive for approval before prosecution. The only concession that the Executive made to the urgency of the epidemic was to allow the Boards to hire a "professional gentleman" to act for the law officers. Under these restraints, the Quebec Board was the most effective at prosecuting offenders but the courts did little to force the population to conform to the

7627 June 1832, 3 July 1832, Minutes vol. 2; 17, 18, 20, 21, 23, 25 August 1832, Minutes vol. 3.

710 May 1832, Minutes vol. 1; Dr. Tessier-Col. Craig 30 December 1832, PAC RG4A1 S-296 pt. II, pp. 155-161; 1st, 2nd, 3rd Report of the committee of the Board of Health, PAC RG4A1 S-292, pp. 138-160; Civil Secretary-Dr. Tessier, PAC RG4C2 1832, vol. 12, p. 208.

17 PAC RG4A1 S-287, p.33; PAC RG4A1 S289, p. 43, 50.

78 Quebec Mercury, 23 August 1832, 28 August 1832; PAC RG4A1 S-290, pp. 161-164; Rapport du Comité Permanent . . ., op. cit., note 63 above. 


\section{First epidemic of Asiatic Cholera in Lower Canada, 1832}

regulations. ${ }^{70}$

The regulations were not popular. There was widespread resistance when the Quebec Board ordered the taverns closed on 16 June. The French and English press agreed that closing taverns denied the poor access to medicinal quantities of liquor prescribed by doctors. Under pressure, the taverns were allowed to reopen early in July. Montreal, wiser perhaps than Quebec, never closed its taverns. ${ }^{80}$ The Boards in Quebec passed regulations binding carters and day labourers to transport the sick and to bury the dead, but in Montreal it took an appeal by the parish priests from the steps of Notre Dame to produce volunteers to dig trenches at Ste. Antoine cemetery ${ }^{81}$ The reports to the Quebec Board of Health by the Wardens in June and July show little effect on the crowded, dirty living conditions of many of the poor.

Some of the health regulations invaded the privacy and property of citizens and some went to the heart of the most intimate problems of life. The Boards required that those who died be buried within six hours. The traditional rituals of church service and tolling bells were denied and the dead were hurried to their graves by hearse, if the family could afford the $\$ 4$ or $\$ 8$ fee (for "common" or "best" hearse) or by the carter if they could not. ${ }^{82}$ There is one case on record of a carter taking a man away for burial despite his wife's protests that he was alive. At the graveside he was found to be alive and his wife took him home. When he later died his wife had to trade his suit to pay for his body to be carried to the burial ground. ${ }^{83}$ Hasty burial gave credence to the widespread rumour and fed the pervasive fear that cholera victims were being buried alive. The Bishop of Montreal assured the curé of a country parish that the rumours seemed to be without foundation but ordered that victims should not be buried within twenty-four hours without the written consent of a magistrate. ${ }^{84}$ Haste destroyed traditional courtesies and public health regulations sometimes met violent resistance. When the magistrates of rural St. Eustache ordered that no cholera victims be buried in the burial grounds at the centre of the village, a mob dug up two bodies which had been buried outside the village. "The putrified carcasses were carried in savage triumph through the village, communicating a stench intolerable as they passed along."85 Arbitrary and intrusive regluations were bound to meet vigorous resistance.

The summer months passed with no end to the epidemic in sight. Despite resistance to the efforts that the Boards did make, public discontent grew with their failure to clean the cities, improve public health or cope with the problems of emigrants, their widows, and orphans. Perhaps because the Montreal Board was less efficient than

79 PAC RG4A1 S-286, p. 14; PAC RG4C2 1832 v. 12, p. 112; PAC RG4A1 S-287, p. 75; PAC RG4C2 1832 v. 12, p. 147, 156; PAC RG4A1 S-288, p. 75, 96; PAC RG4A1 S-290, p. 2.

${ }^{20} 16$ June 1832, Minutes vol. 2; Board of Health-Sec. Craig 25 June 1832 PAC RG4A1 S-284, p. 106; 27 June 1832, Minutes vol. 2; Canadien, reprinted in La Minerve, 5 July 1832; Mercury, 5 July 1832, 12 July 1832, Minutes vol. 2; La Minerve, 14 June 1832.

16 June 1832, Minutes vol. 1 ; Edward Andrew Collard, Montreal yesterdays, Toronto, Longmans (Canada), 1962, p. 61.

${ }_{82}$ Vindicator, 17 July 1832; Alexander Hart-Moses Hart, 19 June 1832, National Archives of Quebec, Hart Papers, microfilm reel 2Gd.

s3 'The life and times of Alfred Perry', [typescript], p. 3, Chateau de Ramezay, Montreal.

si 21 July 1832, Correspondance de Mgr. Jean-Jacques Lartigue, premier évêque de Montreal 1827-1833, Rapport de l'Archiviste de la Province de Quebec 1942-1943, Quebec, 1943.

${ }^{25}$ PAC RG4C2 1832 vol. 12, p. 102; PAC RG4A1 S-286, p. 70. 


\section{Geoffrey Bilson}

that of Quebec, it was there that a volunteer movement first began to supplement the work of the appointed Board. After the seizure of the emigrant sheds left them without shelter, a public meeting led to the establishment of the Committee for Emigrant and Sanitary purposes, headed by Peter McGill, a leading resident and magistrate. Lord Aylmer authorized a grant of funds to the committee for its work with widows and orphans and offered further help for relief for the dependents of residents. The committee built emigrant sheds and rented a store to house them and raised $£ 2000$ for relief. ${ }^{86}$ The committee, and others which were set up in the St. Lawrence suburbs and the East and West Wards of the city, offered the Board the services of voluntary health wardens whose help was readily accepted. ${ }^{87}$ The reports of the volunteer health wardens shocked Montrealers, some of whom supported their vigorous and sometimes brutal actions. When some people were thought to be "refractory" about cleaning their houses in the East Ward, the wardens brought up a fire engine and "played it into the houses in question, till they were thoroughly drenched from the garret to the cellar." Such officiousness brought protests to the Board when it was exercised against people with a higher social position. ${ }^{88}$

The voluntary movement helped to overcome some of the obvious shortcomings of the feeble Montreal Board of Health, but it could not defeat public inertia and hostility toward sanitary reform. Months of effort brought no improvement to the Craig St. Creek which ran through a district badly hit by cholera. The filth and stench from the creek was the immediate cause for the founding of the St. Lawrence suburbs sanitary committee. No solution could be found for the problem because there was not enough money available and little support for the idea of spending public money to clean or cover the creek. Voluntarism had its limits. ${ }^{89}$

In Quebec a public committee was formed late in August to supply voluntary wardens to help the Board's appointees. Within three days, nearly two hundred wardens had been named to serve, and on 1 September a further group were named. The volunteers worked alongside the paid wardens and were also expected to report any failings of those men to the Board. The volunteer wardens reported some nuisances but the later organization of the movement meant that it was less important in Quebec than it was in Montreal. ${ }^{90}$ In both cities, volunteer efforts played the major part in coping with the great human distress of the epidemic and especially in providing for the widows and orphans left by the cholera. The number of these was so great that it overloaded the resources of the church bodies such as the Grey Nuns and the Seminary in Montreal which traditionally supported these unfortunates.91 In July, there were one hundred and eighty-eight widows, eleven widowers, and

\footnotetext{
s6 Montreal Gazette, 23 June 1832; C. J. Forbes-Col. Craig, 24 June 1832, 25 June 1832, 26 June 1832, PAC RG4A1 S-284, p. 91, 92, 105; Col. Craig-C. J. Forbes 27 June 1832, PAC RG4C2 1832, vol. 12, p. 87; La Minerve, 25 June 1832; Canadian Courant, 27 June 1832; C. J. Forbes-Col. Craig 3 July 1832 PAC RG4A1 S-285, p. 18; Vindicator, 4 June 1833.

${ }^{87} 10$ July 1832, resolution of the committee, Montreal Gazette, 1 August 1832; Canadian Courant, 8 August 1832.

is Ibid.,15 August 1832, 18 August 1832, 22 August 1832.

2 Ibid., 28 July 1832, 1 August 1832; Montreal Gazette, 14 August 1832.

${ }^{\circ}$ Quebec Mercury, 21 August 1832, 22 August, 24 August, 25 August, 1 September, 13 September 1832, Minutes vol. 3

1 Canadian Courant, 7 July 1832.
} 
three hundred and forty-eight children being cared for in Quebec, while in the winter, the Montreal Society was still supporting forty-one widows and over two hundred children, despite its efforts to place them in private homes. ${ }^{92}$

\section{THE EPIDEMIC OUTSIDE QUEBEC AND MONTREAL}

The cholera epidemic was not confined to the major centres of the province. The pattern of traffic and the dispersal of immigrants almost guaranteed that cholera would spread along the river settlements. The fact that cholera might occur outside the cities was recognized by the provision for subordinate Boards of Health to be appointed when they were needed. The first communities to suffer were those that served as staging posts for the emigrant traffic. Shortly after, communities linked by trade or by land routes to the riverside settlements began to suffer and by the end of the epidemic the disease had been seen in most parts of the province. The panic which drove hundreds out of the cities helped to spread the disease and some rural communities tried to protect themselves by barring the entry of strangers or the return of residents who had travelled to Quebec or Montreal..$^{93}$ The citizens of Three Rivers set up a Board of Health on first hearing of the outbreak and closed the town to most river traffic. Vessels visiting Three Rivers had to anchor in the stream, be inspected by the local Health Officers, and land passengers only for the town. The quays were fenced off and residents barred from them. The precautions were expensive but were widely believed to have saved Three Rivers from the disease. The government objected to the expenditure on the grounds that it was greater than justified in the absence of disease. ${ }^{94}$ Despite its precautions, Three Rivers did have a cholera epidemic with thiry-two cases and sixteen deaths between $13 \mathrm{June}$ and $10 \mathrm{July}{ }^{95}$

Anticipating and fighting cholera involved heavy expenses and the provincial government urged economy on local communities and expected the Quebec and Montreal Boards of Health to supervise expenditure of subordinate boards and keep them below $£ 300 .{ }^{96}$ Efforts were made to anticipate probable outbreaks of the disease by appointing boards in places thought particularly vulnerable, such as Gaspé, which had a heavy international traffic and where the residents were especially alarmed that cholera would occur. ${ }^{97}$ In fact, it never did break out there. Elsewhere, subordinate boards were established when cholera broke out, as at Chambly where emigrants on the canal brought the disease on 15 June. By early July, sixty-five people were dead of the disease and it lingered on with reduced violence until late in the year causing great panic but few deaths among the workers building the canal..$^{98}$ In all,

\footnotetext{
'2 Quebec Mercury, 31 July, 7 August 1832; Report of Annual Meeting, Montreal Orphan Asylum 15 January 1833, Montreal Gazette, 17 January 1833.

os 13 July 1832, 14 July 1832 , Minutes vol. 2 .

o4 PAC RG4A1 S-283, pp. 113, 114, 119; PAC RG4A1 S-284, pp. 95-96, 164-164a, PAC RG4C2 1832 vol. 12 , pp. $92,103$.

${ }^{95}$ Canadien, 2 July 1832, reprinted in La Minerve 5 July 1832; Canadian Courant, 1 September 1832; La Minerve, 14 July 1832.

" Provincial Secretary-Board of Health Montreal, 21 June 1832, PAC RG4C2 1832 vol. 12, pp. 75-76.

'7 PAC RG4A1 S-280 pt. 1, p. 17, 154, 156; PAC RG4C2 1832 vol. 12, p. 49; PAC RG4A1 S-283, p. 123; PAC RG4A1 S-284, p. 5.

'8 PAC RG4A1 S-284, p. 120, 160; PAC RG4A1 S-285, p. 31, 61, 100, 122; PAC RG4A1 S-287 pt. II, p. 122, 134; PAC RG4A1 S-293 pt. II, pp. 139-139a.
} 


\section{Geoffrey Bilson}

ten subordinate boards were established during the summer of 1832 , at Gaspé, Three Rivers, Chambly, William Henry, St. Johns, Soulanges, Berthier, La Prairie, Beauharnois, and St. Hyacinthe.

The cholera lingered on through September and into October, with a stubborn two or three deaths a day in the major centres. About mid-October it seemed that the epidemic was over, and the port of Montreal issued clean Bills of Health to departing vessels once more. ${ }^{99}$ No-one knew how many people had died, the official estimate, based on returns to the Board of Health was 3451 for Quebec. Private estimates ran higher, Dr. Nelson thought that four thousand had died, in Montreal and district alone, and a petition addressed to the House of Assembly from Montreal claimed that the epidemic had "slain above TWELVE THOUSAND victims in Lower Canada!!" A. C. Buchanan reported that the "total extent of deaths among the Emigrant Population of this year in both Provinces did not exceed 2350."100 That was about five per cent of the emigrants. There was general agreement among commentators that Lower Canada had been hit harder proportionate to her population than any European nation. The variation in the figures was partly a consequence of incomplete statistics but partly also a reflection of the political division in the province with a heavy death toll standing as criticism of the administration of Lord Aylmer.

Aylmer was criticized for keeping the Boards short of funds so that he would not have to call the legislative assembly into session to ask for a further grant. ${ }^{101} \mathrm{He}$ himself noted that the first outbreak had brought an end to the public meetings organized to protest the events of 21 May, although that protest soon resumed. ${ }^{102}$ Charges were made that the Boards of Health were used as sources of patronage and that the secretaries of the Quebec and Montreal Boards were overpaid. ${ }^{103}$ On the other hand, the voluntary organizations were praised for their greater effectiveness and pointed to by one critic of the administration as examples which "we hope will convince the advocates of 'Authority' that it is best administered when in the hands of citizens, who will take pains in giving inhabitants proper information on the object in view ...".104 The political impact of the epidemic should not be exaggerated - Ludger Duvernay, a controversial editor deeply involved in the incidents of 21 May, gave that event five lines in his account of the outstanding events of the year 1832 in his Nouvel Almanac. He gave half a line to the cholera epidemic. ${ }^{105}$ On the other hand, the impact cannot be ignored. When Parliament opened in November, incidents from the epidemic were used for tactical advantage in the debates. The speaker, L. J. Papineau, supported a motion to ban T. A. Young from his seat on the grounds that he had taken money from the Executive as Secretary of the Board of Health of Quebec. The motion was lost. ${ }^{108}$ Aylmer's request for funds to meet the cost of o 18 October 1834 PAC RG4A1 S-292, p. 23.

100 Bulletin des Recherches Historiques, 1906, 12: 88-92; J. J. Heagerty, Four centuries of medical history in Canada, Toronto, Macmillan, 1928, vol. I, p. 187; Vindicator, 20 November 1832; Buchanan, op. cit., note 4 above, p. 49 C.O. 42/241.

101 La Minerve, 9 July 1832.

${ }^{102}$ Lord Aylmer-Lord Goderich 6 July 1832 C.0. $42 / 237$.

10828 June 1832, PAC RG4C2 1832 vol. 12, p. 86; Vindicator, 3 July 1832.

106 Canadian Courant, 15 August 1832.

${ }^{105}$ Lord Aylmer forwarded the Almanac in his despatches with critical passages marked, C.O. 42/241.

106 Canadian Courant, 13 February 1833. 
the epidemic led to a long wrangle over the money bill and Parliament failed to renew the Quarantine Act for 1833. Public petitions in Montreal criticized the Executive for failing to protect the people from the epidemic by regulating the emigrant traffic-a charge which administration supporters dismissed as that of anti-British factions "blinded by the madness of the party."107

\section{v. CONCLUSION}

Cholera was a disease which encouraged international co-operation by health authorities in the nineteenth century. The first efforts to reach agreement on the nature of the disease and the best means of controlling it were unsuccessful because local needs made different theories about the disease more or less attractive in different countries. Even within a given country, as Asa Briggs has pointed out, responses to an epidemic of cholera varied according to local circumstances. ${ }^{108}$ In 1832 , Lower Canada responded in its own way to the cholera and within its borders some communities responded more successfully than others.

Canadian doctors and laymen were as confused by the disease as were those everywhere, but they were as well informed about it as any people. The discussion of the etiology of the disease was shaped by information from England both through the official correspondence of the government and the informal communications printed in the newspapers. Some men in Lower Canada had seen the disease in India. The information from England was supplemented by reprints from French newspapers which appeared in both the English and French papers in Lower Canada. The newspapers also printed reports of the epidemic in Russia and Eastern Europe. On the basis of this information and their own observations, Canadian doctors debated the question of cholera and generally accepted that it was not contagious. Divisions over the emigrant question influenced some opinions. French doctors were more prepared to see a link between emigrant ships and the disease than were some English doctors who inclined to the idea that climatic conditions created the disease and looked for evidence that it had broken out in parts of the province remote from the St. Lawrence. ${ }^{109}$ The doctors exposed their patients to all the therapies applied to the disease in Europe and the United States, leaning heavily on calomel, opium, and bleeding. The desperately sick were not safe from the most extreme remedies practised elsewhere. As early as June 1832, Dr. Joseph Morrin of Quebec was reported to have tried saline injections in patients in collapse "but owing to unfortunate circumstances, the success which at one time appeared certain, failed. Experience will probably improve this mode of treatment."110

Canadian doctors did not have access to the carefully detailed statistics which were beginning to play an important part in medical investigations. Lower Canada did not support a government apparatus which could collect that kind of information

107 Vindicator, 20 November 1832; Montreal Gazette, 14 December 1832.

${ }^{108} \mathrm{~N}$. Howard-Jones, 'The scientific background of the International Sanitary Conferences 1851-1938' Pt. I, W.H.O. Chronicle, 1974, 28: 159-171. Asa Briggs, 'Cholera and society in the nineteenth century., Past and Present, 1961, 19: 76-96.

109 Helen Taft Manning, The revolt of French Canada 1800-1835, Toronto, Macmillan (Canada), 1962 , p. 202.

${ }_{110}$ Quebec Mercury, quoted in Canadian Courant, 1 August 1832. 


\section{Geoffrey Bilson}

and it is impossible to reconstruct for this epidemic the elaborate demographic analyses which the statistics yielded for France and England. ${ }^{111}$ Contemporaries were aware that some parts of the cities were harder hit than were others and that the poor were the greatest sufferers, but they could not refine that perception into any more precise analysis by occupation, age, or sex. In their explanation of the disease, Canadians noted its impact on the poor but that tended to confirm their suspicions that moral failings had some influence in predisposing victims to cholera. One pattern that was recognized was that the disease showed an increase in cases on Mondays, and Canadians, like their French contemporaries, ascribed that to the weekend debauches of the poor. Canadian doctors advised against excess in diet and behaviour and recommended that people stay calm, keep clean, keep their feet dry, and stay warm.

The advice, for most people, was useless and the doctors were seen to be divided and helpless. In the United States, loss of confidence in the profession helped to make Thomsonianism popular by undermining the doctors' claim to special knowledge. In Europe, the profession faced more dangerous challenges as the people rioted against the doctors out of fear of premature burial or fear that the victims were being used for dissection. Where social or political tensions were very high, doctors were attacked as agents of the government sent amongst the people to kill them, not cure them. ${ }^{112}$ The doctors in Lower Canada faced some hostility but no violence. There were some accusations, late in the epidemic, and in the years which followed, that cholera had been introduced to kill the French Canadians, but those accusations were directed against the British government and the emigrant traffic and there was no need to accuse the doctors of moving among a healthy population to poison them. ${ }^{113}$ The Canadian medical profession was not well established and its claims to privilege were not of long standing. The number of applicants for positions with the Boards of Health at fifteen shillings a day suggested that many doctors were in financial trouble. As a profession, medical men were divided on racial, political, and linguistic lines and could unite only with difficulty. The Canadian people, in 1832, took a line closer to that of Americans than that of Europeans by ignoring the doctors rather than attacking them and by turning to their neighbours or, in Montreal, to Stephen Ayres, for help.

The government of Lower Canada had the power to impose a rigorous quarantine. The decision to do so was not popular but the merchants could not prevent it nor effectively protest against the Quebec Board of Health's decision to intensify the quarantine in July 1832. Despite their influence, the mercantile community could not deny the presence of the disease in the city as had the local rulers of Sunderland

111 E.g. Louis Chevalier, Labouring and dangerous classes in Paris during the first half of the nineteenth century, New York, Howard Fertig, 1973, 345-349 and passim. Catherine Rollet and Catherine Souriac, 'Epidémies et mentalités: le cholera de 1832 en Seine-et-Oise', Annales Economies Sociétés Civilisations, 1974, 29: 935-965. M. Durey, The first spasmodic cholera epidemic in York. 1832, York, University of York Borthwick Institute of Historical Research, 1974.

112 Charles E. Rosenberg, The cholera years, Chicago, University of Chicago Press, 1962, p. 72; Durey, op. cit., note 111 above, p. 24; Thomas Shapter, The history of the cholera in Exeter in 1832, London, John Churchill, 1849, republished London, S. R. Publishers, 1971, pp. 236-239; Rollet and Souriac, op. cit., note 111 above, p. 963; Roderick E. McGrew, Russia and the cholera 1823-1832, Madison and Milwaukee, University of Wisconsin Press, 1965, pp. 106, 116.

118 Manning, op. cit., note 109 above, p. 202. 


\section{First epidemic of Asiatic Cholera in Lower Canada, 1832}

in the previous autumn. ${ }^{114}$ Smaller communities, such as Three Rivers, and the villages along the Craig's Road which many emigrants followed to the U.S.A., set up their own quarantine. The local governments of Upper Canada blocked travel into the province and caused delays and difficulties for the travellers held up in Montreal. None of these quarantines prevented the spread of the disease along welltravelled routes. When the disease struck, people fled the cities and the emigrant agents hurried new arrivals on their way as quickly as possible. Given the high state of political tension in Lower Canada it was fortunate that this was so. On Grosse Isle, where the emigrants were kept under the watch of the army, there were daily scenes of disorder and crime among the unfortunates packing its limited space. In later years, the commandant would ask for the powers of a magistrate in order to deal summarily with disorder. The cities of Lower Canada had neither the desire, nor the force, to establish effective blockades against infected localities. They were therefore spared the Russian experience, where the worst disorders took place when the quarantine against residents of a town was most strictly enforced. ${ }^{115}$ Flight not only reduced the concentration of population but helped to reduce the tension in a community.

The government of Lower Canada lacked the machinery to gather statistics because it lacked the machinery to enforce regulations. In France and in Russia, by contrast, the bureaucracy bore heavily on the people. Briggs has suggested that of all the social irritants producing violent reactions to cholera epidemics in some places in Europe "the most powerful . . . was the fear of bureaucracy." 116 The government of Lower Canada had the potential to create problems, as its insistence on following the regular channels of the law in prosecuting cases showed. When local Boards of Health, in the face of the emergency, tried to prosecute those who broke sanitary laws, the Governor-General insisted that they do so in the regular way. The normal pattern could not be changed. Had the same inflexibility been applied by an elaborate structure of local government to an extensive code of regulations, Lower Canada might have witnessed scenes such as those which occurred in some European countries. It can be suggested that the feebleness of government spared Lower Canada from more difficulties than she had to face in $\mathbf{1 8 3 2}$.

The troubles of 1832 took a largely political form through protest meetings and resolutions, and against that background the mildness of the response to cholera regulations is striking. It is clear that there was widespread resentment of the regulations which were invoked. That resentment could build into open hostility as it did at St. Eustache. On the other hand, complaints against the location of cholera hospitals were restrained. Petitions were used in 1832 to protest against cholera hospitals, the torch would be used in the future. A steady pattern of inertia and defiance is visible in the response of common people to the sanitary regulations of the Boards of Health. They lacked the money or the materials to improve their living standards, they feared the hospitals and they felt themselves abused by a system which allowed a carter to decide whether a poor man was alive or dead. A more

\footnotetext{
111 N. Longmate, King Cholera, London, Hamish Hamilton, 1966, p. 31.

118 McGrew, op. cit., note 112 above, p. 51.

110 Briggs, op. cit., note 108 above, p. 82.
} 


\section{Geoffrey Bilson}

stringent enforcement of the regulations might have been met with a more violent response.

The provincial government passed on the responsibility for fighting cholera to local bodies supported by the public funds. The local responses varied greatly. Quebec was prepared to meet the epidemic, Montreal was unprepared. Some subordinate boards were vigorous and willing to enforce regulations but the epidemic exposed the inefficiencies of local governments and the unmet needs of the cities and towns. It did not immediately provoke reforms. When the Boards of Health failed, volunteer organizations took up the work and their actions hint at the class divisions of the communities. While there was not the assault on the lower-class parts of the towns which marked the response of Paris to the epidemic, there were brutalities and officiousness in enforcing sanitary laws. Cholera revealed poverty and the appalling living standards of many of the poor, if not for the first time then certainly in a most dramatic way, to the middle classes of the cities. It did not change their attitudes toward the poor. The church emerged with credit from the epidemic. It enjoyed wide popular support and, unlike the United States, there were no protests against a public declaration of a day of humiliation. The work of the priests and nuns was widely approved but their efforts had to be supplemented by secular charity in the face of the great disaster. The relief of widows and orphans was marked in Montreal, as in Exeter, by a vigilance against the undeserving poor. The voluntary action to meet the needs revealed and created by the epidemic had limits both of will and of finance. It could not solve the problems which local government had neglected.

1832 was a year of political crisis for Lower Canada and that crisis saw a division of the French politicians which led to the triumph of radicals over moderate opinion and set the colony on the path toward open rebellion. ${ }^{117}$ No direct link can be demonstrated between political events which had their roots in long-standing divisions in the province, and the epidemic of 1832, but it would be perverse to deny that the tensions produced by cholera affected the population. The death toll was high, by conservative count Lower Canada lost almost as many people as Glasgow, from a population about half that city's size. 118 The demographic impact of the disease was reduced by the fact that many of the deaths took place amongst emigrants who did not plan to settle in Lower Canada. The fact of death in unknown numbers was part of the experience of all Canadians in 1832 and to some the presence of the disease was a consequence of British policies. The estimates of the death toll grew higher as the estimators grew more estranged from the government. The shortcomings of government remained, even if they spared Lower Canada from the disorders that more heavily bureaucratic countries faced. The epidemic contributed to the psychological, social and political strains of the community and when cholera returned in 1834 it would be met with harsher criticisms of government, stronger accusations and more violent responses from a society closer to revolution.

\section{SUMMARY}

Asiatic cholera reached Lower Canada in June 1832, despite quarantine regulations.

117 Manning, op. cit., note 109 above, Chap. XX.

118 Longmate, op. cit., note 114 above, pp. 58-59. 
Provincial and local government efforts to provide hospitals and enforce public health regulations were erratic. Large numbers of emigrants strained the resources of the province and helped to spread the disease along the river system and overland to almost all parts of Lower Canada. The first responses to the epidemic were panic, flight, and avoidance of emigrants. After two weeks the panic subsided and people began to come to terms with the epidemic which lasted until autumn, killing approximately 8000 people. Canadian doctors shared the bewilderment of European and United States doctors over the nature of the disease and its cure. They employed all therapies tried elsewhere. Public confidence in the profession dropped but doctors were not assaulted as they were in places in Europe. Voluntary action was needed to supplement government action in most communities. Cholera contributed to the tensions of a year marked by ethnic and political division but those tensions did not reach the heights that they did in France or in Russia, partly because the bureaucracy of government in Lower Canada was rudimentary. 